\title{
The degradation of Brazilian socioeconomics
}

\author{
A degradação da socioeconomia brasileira
}

MARCUS ALBAN*

RESUMO: O Brasil nos últimos anos vem se caracterizando pelo desenvolvimento de uma série de atividades ilegais. Para compreender essa dinâmica, não considerada nas análises convencionais, propõe-se um Modelo Keynesiano Expandido, no qual as crises são explicadas pela substituição de atividades produtivas por atividades improdutivas e destrutivas. Com o modelo se analisa a trajetória socioeconômica desde o Plano Real, concluindo que, como a preocupação foi preponderantemente com a estabilização e não com o crescimento, as atividades produtivas nunca foram viabilizadas na escala adequada, abrindo o espaço para o avanço das improdutivas e destrutivas, que provocam uma crescente degradação do país.

PALAVRAS CHAVES: Economia Brasileira; Nova Economia Institucional; Economia Keynesiana; Economia da Criminalidade.

ABSTRACT: In recent years, a number of illegal activities operated under the radar of conventional analysis have taken place in Brazil. This study proposes an Extended Keynesian Model in order to understand this phenomenon, a model that explains that crises happen because of the replacement of productive activities with unproductive and destructive activities. The model is used here to examine Brazil's socioeconomic history since the institution of the economic plan that established the actual currency "Real" (R\$), concluding that as the plan's concern was predominantly with stabilization and not growth, productive activities have never been promoted on an appropriate scale. This has paved the way for the advancement of unproductive and destructive activities which have ultimately led to the country's increasing degradation.

KEYWORDS: Brazilian Economy; New Institutional Economics; Keynesian Economics; Economics of Crime.

JEL Classification: B52; E02; E12; K42.

\footnotetext{
* Professor Titular da Escola de Administração da Universidade Federal da Bahia. E-mail: m.alban@uol. com.br. Submitted: 28/December/2016; Approved: 17/February/2017.
} 


\section{INTRODUCTION}

Considering characteristics such as location, geographic dimension, natural resources, linguistic unity and reasonable ideological/religious harmony, it is possible to say that Brazil has the conditions to be a major socioeconomic power. This set of conditions has led many authors to call Brazil the "country of the future". However, it seems that this 'future' is not even close to becoming a reality and, today, one could say this future is about to vanish. Why is this happening?

The New Institutional Economics (NIE), explains this situation pointing out the absence of strong institutions guaranteeing the right to property, a condition that, to some extent, is a result of Iberian colonization and did not provide the confidence required for continuous and growing innovative investment. ${ }^{1}$ In a more contemporary version of the NIE there would be "extractive institutions" which, to keep the monopoly in the hands of a small group, would not allow free access to all to the innovative investment process and its benefits. However, analyzing the Brazilian case, it is possible to conclude that with recent democratization, "inclusive institutions" have finally been created, which allow the emergence and access to power of parties, such as the Brazilian Social Democracy Party (PSDB) and, the Workers' Party (PT). This would explain the "quick economic growth with poverty reduction" (ACEMOGLU and ROBINSON, 1990, p. 353) since the 1990s.

As is well known nowadays, Brazil is facing a new crisis, which appears very far from being overcome. At this time it is an extended crisis which, in parallel to long-standing economic problems - disparities in public accounts and a long period of growing inflation - has been associated to levels of violence/crime and corruption that are out of the country's historic standards. All this, at least until the end of President Dilma's first term, was accompanied by considerably low unemployment rates. The aim of this article is to contribute to understand this new crisis, which looks more like a new modus operandi of Brazilian socioeconomics.

\section{THE PARADOX OF EMPLOYMENT}

With the growth reacceleration of the Brazilian economy during President Lula's first term (Worker's Party - PT), unemployment - as expected - started to fall almost uninterruptedly, and continued to decrease until the end of Lula's second term. Surprisingly, the decline continued despite the downturn/stagnated economic growth in the third term of PT's government (the first of President Dilma Rousseff (see Chart 1). The reason for this phenomenon was that the job creation slowed down and fell because of decrease in GDP's growth, but at the same time, there was a decline in participation rate, i.e. a decline in the number of people able to work

\footnotetext{
${ }^{1}$ The original NIE development model, formulated by Douglas North, is presented in the fourth section.
} 
and looking for jobs. This situation was responsible for the maintenance of the fall in the unemployment rate.

Graph 1: Evolution of Unemployment Rates and Real GDP Growth

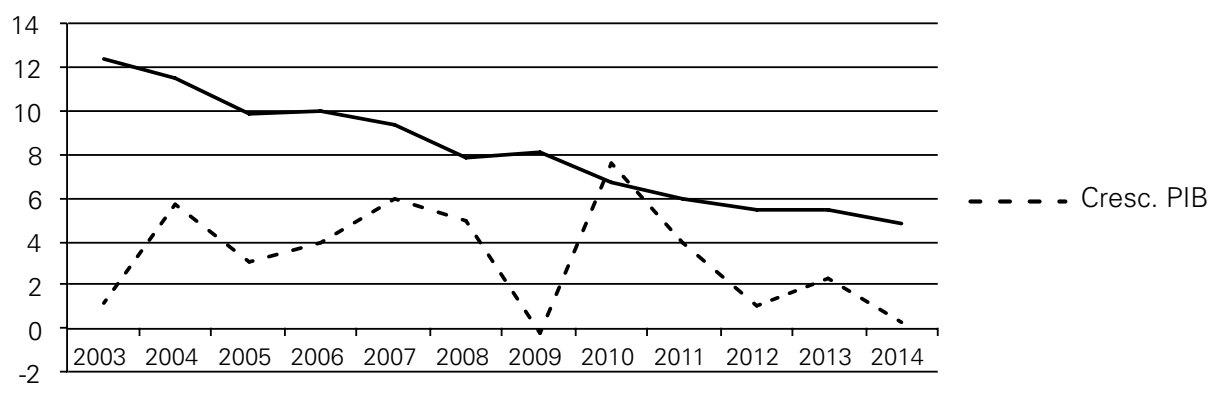

Source: Brazilian Institute of Geography and Statistics (IBGE).

Explaining the reason for the unemployment rate to keep falling, it is worthwhile considering why the participation rate is lower in this context when the exact opposite would be justifiable? Generally speaking, two explanations are proposed for this phenomenon. The first, defended by the economist, Naercio Menezes, among others, is focused on the improvement of salaries of adult heads of households, which would allow a higher percentage of young people to be dedicated exclusively to education or - in a smaller number - idle and perhaps allocating more time to finding a better job. Menezes observes that this process would not necessarily lead to higher gains in productivity: it would depend on what young people are doing with more free time, whether "doing more homework or playing more football?" (2014).

The second explanation, defended by economists, such as José Marcio Camargo, also sets off from the increased income of heads of households in recent years but adds the rise in costs of working outside the home, which would make a higher percentage of women and young people, considered "secondary members of the work force", to choose to stay out of the market. ${ }^{2}$ As observed, both explanations state that there was a general improvement in salaries, particularly for heads of households, in theory allowing families to be more harmonious, in a more balanced society, where not everyone needed to look for a job. Thus, unusually, even with the economic downturn, a growing part of the Economically Active Population (EAP) could focus purely on education, looking for better jobs or simply taking better care of the home.

\footnotetext{
${ }^{2}$ It should be emphasized that this point of view was presented by Camargo in journalistic interviews held by IstoÉ Dinheiro (published in the 08/08/2014 edition entitled "Está muito caro trabalhar no Brasil") and by Folha de São Paulo (published in the 09/01/2015 edition, entitled "Com desistentes, taxa de desemprego no Brasil seria quase o dobro da atual” in an article by Érica Fraga).
} 
It is important to observe that Menezes and Camargo's hypotheses are not merely rapid analyses, elaborated to feed articles and interviews in newspapers. In fact, this was the dominant point of view at the time, as noted in the position taken by the Climate Study Group (GECON) at the Institute of Applied Economic Research (IPEA), in its Outlook Letter Number 22:

The incorporation of real raise in salaries in recent years, allied to the increased number of people benefiting from government social programs, has been producing a growth in income, so that young people can leave the labor market and return to education, among other objectives. [...] [Thus] if it is really confirmed that a large proportion of young people who are leaving [...] have done this to further their education, it could be assumed that there will be a higher qualified labor force in the economy in the medium term, implying gains in productivity (2014, p. 34).

It should be added that both Menezes and Camargo observed that this was an unsustainable trend and that it should cease, as indeed it did, with the advance in the downturn of the economy. As confirmed, the unemployment rate started rising once more at the beginning of 2015, in President Dilma's second term. However, this does not eliminate the question of why it took so long for this trend in the unemployment rate to naturally start rising again with the economic downturn. It is important to emphasize that it is not a marginal anomaly. With the participation rate in effect in 2012 remaining constant, when the downturn worsened, the unemployment rate at the end of 2014 was approximately $8 \%$ and not under $5 \% .^{3}$

Although the data available was not incoherent, with a certain social optimism (implicit in analysis such as those by Menezes, Camargo and IPEA), it can be assumed that it may not have been correct, or at least not totally correct, in explaining the full complexity of the process. In fact, it is difficult to accept that with such an economic downturn, which caused the loss of numerous jobs (especially in industry), the unemployment rate continued to fall throughout Dilma's first term because of an expressive and growing percentage of young people and women who chose not to look for a job.

On the other hand, it should be noted that President Dilma's first term was not a timeframe in which Brazilian society was reassured, to justify a constant fall in the participation rate, as the above-mentioned analysis implicitly assumes. On the contrary, in addition to re-accelerated inflation, this was a period of growth for rates of violence and crime, associated with the emergence of the corruption scandals and weakening political harmony and the hegemony of the Worker's Party in the country. ${ }^{4}$ Thus, it is no coincidence that the country practically came to a stan-

\footnotetext{
${ }^{3}$ Values estimated by André Gamerman and José Marcio Camargo (FRAGA, 2015).

${ }^{4}$ For the evolution of rates of violence during the period, see Waiselfisz (2014).
} 
dstill on account of major mass movements in 2013 and, President Dilma (PT) was re-elected in 2014, but with a very slim margin.

As can be observed, attributing the constant fall in the rate of unemployment during Dilma's first term solely to the improvement of income of heads of households is quite complex. However, if it was not solely improvements in salaries, what else could explain this unusual relation between the economic downturn and the reduction in the rate of unemployment?

\section{INCORPORATING ILLEGALITY INTO THE ANALYSIS}

Although relevant, illegal issues such as crime, violence and tax evasion and corruption, are not part of analysis or of conventional macroeconomic models. They are understood as marginal phenomena and/or a 'noise in the system', to be tackled by specific government areas of safety and justice. However, in Brazil these issues reached such dimensions that it was not possible to deal with them in this way. In fact, at least in recent years, phenomena such as crime, violence, tax evasion and corruption are, directly and indirectly, economic vectors of great importance today, generating an infinity of formal, informal and illegal jobs, which need to be taken into account.

As these activities are not understood as marginal and not necessarily economic phenomena, they are rarely studied. Thus, in order to have an idea of their magnitude, the alternative is to draw on articles in newspapers and on the evolution of data which may form reasonable proxies for these phenomena. To this end, Table 1 shows the evolution between 2004 and 2013 of the number of inmates and the income and number of security guards from private security companies in the country. As can be observed, in all series there is evolution with rates of growth much higher than those obtained by the GDP in the same period for all of the items.

Table 1: Evolution of Private Security and the Prison Population

\begin{tabular}{|l|r|r|r|}
\hline & \multicolumn{1}{|c|}{2004} & \multicolumn{1}{|c|}{2013} & \multicolumn{1}{|c|}{$\begin{array}{c}\text { Average \% } \\
\text { of Growth }\end{array}$} \\
\hline Prison Population (in thousands) - (a) & 336.4 & 581.2 & 6.3 \\
\hline $\begin{array}{l}\text { Income of Private Security Companies } \\
\text { (in R\$ billion in 2013) - (b) }\end{array}$ & 19.5 & 43.5 & 9.3 \\
\hline Number of Private Security Guards (in thousands) - (b) & 400.0 & 635.0 & 3.3 \\
\hline $\begin{array}{l}\text { Evolution of GDP, real change } \\
\text { 2004 Base 100 - (c) }\end{array}$ & 100.0 & 140.2 & 3.8 \\
\hline
\end{tabular}

Sources: a) DEPEN (2014, p. 15); b) FENAVIST (2014, pp. 6, 44) and c) IBGE. Note: The data on private security companies for 2004 was adjusted to the values of 2013, using as base the implicit deflator for GDP during the period.

It is important to note the magnitude of totals in these variables. The total number of inmates in 2013 for example, represented $0.52 \%$ of the country's 
Economically Active Population (EAP) in that year. The number of private security guards in 2013 comes to $0.67 \%$ of the EAP. ${ }^{5}$ Based on these figures, it is clear that there are reasons much more perverse than the increase in heads of households' salaries for the reduction in participation and unemployment rates throughout Dilma's first term. In fact, a percentage of the jobs were not those for production but jobs designed to combat and prevent crime. The statistics presented in Table 1 consider only security guards from formal companies. There are also administrative employees at these companies and informal security guards, estimated at approximately three times the number of those formally employed. ${ }^{6}$ On the other hand, part of those who stopped looking for work did not do that exactly to pursue education, play football or just stay at home (as Menezes and Camargo suggested). Part of this population engaged in criminal activities and some were arrested.

In contrast, in relation to tax evasion, studies performed by the Institute of Social and Economic Development of Frontiers (IDESF) estimate that market losses with smuggling alone were in the order of $\mathrm{R} \$ 100$ billion per year $(2015)^{7}$. Lastly, with regard to corruption, although there are no consolidated numbers, the data released by Operação Lava Jato (Operation Car Wash), involving the problems associated with Petrobras (Brazilian state-owned oil company), suggests that annual misappropriation and losses in this segment are of a magnitude much higher than those generated in smuggling activities. All of this involves a myriad of informal, illegal jobs and/or misappropriation and parallel civil service roles - including judges and politicians - and private jobs.

As observed, problems of crime, violence and tax evasion really cannot be disregarded in an analysis of the Brazilian reality. Those are central issues and they directly and indirectly employ/occupy an ever increasing segment of the EAP. In the next section this article tries to understand this context, exploring why the crisis and lack of economic growth is not reflecting in an increase in unemployment, as well as what should be done to overcome this degradation process that seems to be progressing with no limits? It is clear that, in order to try answering these questions, a much broader vision of economic dynamics is required.

\section{NIE AND THE EXTENDED SCHUMPETERIAN MODEL}

In 1981, in his research 'Structure and Change in Economic History', Douglas North consolidates NIE, creating a new theory of economic development from

\footnotetext{
${ }^{5}$ Percentages calculated based on the EAP estimated by PNAD for 2013, which counted 102.6 million people.

${ }^{6}$ Estimate made by the Trade Union for Private Security of the State of Rio de Janeiro - Sindesp RJ (PONTES and CÂNDIDA, 2006).

${ }^{7}$ These same numbers were presented by organizers of the "O Contrabando no Brasil" (Smuggling in Brazil) Forum, promoted by Folha de São Paulo in March 2015.
} 
institutional evolution. In his work, the author argues that the State is considered the great formulator of regulations and institutional arrangements that ensure the right to property and the reduction in transaction costs to allow, via competition and cooperation, an appropriate allocation of resources for economic growth.

In this context, institutions should be designed to guarantee ethical behavior and reduce transaction costs. Therefore, it sets off from the theorization to attempt to build institutional arrangements able to encourage agents to invest in efficient and productive activities. However, North realized that institutional arrangements do not always guarantee the positive evolution of societies. Or, in other words, they do not always guarantee development. Thus, in 'Institutions, Institutional Change and Economic Performance', in 1990, North formulates a new version of his theory.

In this second version, institutions continue to be the main support for the analysis. They will determine the rules of the political and economic game. However, they cannot be summed up in formal rules. They will incorporate informal institutions and rules, present in every nation's culture and ideology. With this broader vision, the regular implementation of his theory is naturally greatly affected.

The problem is not limited to the 'timing' of the change, and the fact is that institutions and organizations are together. According to North, if the institutions are the rules of the game, the public and private organizations are the players. Interacting with the institutions, the organizations determine the socioeconomic performance and evolution of the system, which will not always be positive. North defends that through a path dependence process, inefficient institutional arrangements can be developed and persist for a long time.

With no doubt, based on the 'path dependence' dynamics suggested by North, it is possible to explain why policies of institutional modernization have not been sufficient to contain corruption or ensure the process of development in countries such as Brazil. But why has this situation continued for such a long time?

In order to make progress on this issue, another institutional approach has to be incorporated. It is the approach proposed by William J. Baumol in 'Entrepreneurship: Productive, Unproductive and Destructive' (1993). ${ }^{8}$ In general terms, Baumol starts by criticizing the economic development model proposed by Joseph Schumpeter.

For Schumpeter, development is an outcome of the technological innovation process undertaken by businessmen and companies. In his words:

The fundamental impulse that sets and keeps the capitalist engine in motion comes from new consumer goods, the new methods of production or transportation, the new markets, the new forms of industrial organization that capitalist enterprise creates. [...] [The creation of all these items], from the small-scale workshop to the large conglomerates,

\footnotetext{
${ }^{8}$ William Baumol's seminal article was originally published in the Journal of Political Economy, 1990, vol. 98 , n. 5 .
} 
[...] [ illustrates] the same process of industrial mutation [...] which incessantly revolutionizes the economic structure from within, incessantly destructing the old and [...] creating a new one. This process of Creative Destruction is the essential fact about capitalism. (1984, pp. 112-3).

With this vision, Schumpeter envisages the process of development as something essentially cyclical. The argument is that the appearance of entrepreneurs or simply innovations, does not take place through a uniform distribution in time. On the contrary, they tend to arise concentrated in certain times, causing cyclical oscillations in the economy. However, Schumpeter has never managed to provide a good explanation for this cyclicality and why there are groups of entrepreneurs at specific periods and not others. It is from this fragility that Baumol's analysis is developed, proposing what he calls the Extended Schumpeterian Model.

For Baumol, the possibilities of the innovative activities proposed by Schumpeter need to be extended, incorporating unproductive innovations - those that merely prey on the income already existing in the economy - as well as destructive innovations, i.e. innovations that increase revenues for some organizations on the expenses of the society as a whole. With this hypothesis, Baumol assumes that the existing entrepreneurial capacity is constant and, thus, it is the type of innovation and the dominant activities (if productive or unproductive-destructive) that determine whether an economy experiences periods of development, or stagnation and crisis.

Although accepting the hypotheses of a constant entrepreneurial capacity, Baumol argues that entrepreneurs of constructive innovations and activities will not necessarily be the same as those of unproductive and destructive ones. Given each one's talents and expertise, not all of them will have the capacity and desire to undertake productive activities, with the same being true for unproductive and destructive activities. But what determines a decision on the type of innovations and activities and, consequently, of entrepreneurs?

Like North, Baumol argues that the rules of the game are determinant. The rules will determine the payoffs for each type of activity. Thus, if unproductive and destructive activities are accepted and not punished, they tend to become dominant, naturally suffocating productive innovations and activities. However, if the opposite occurs, i.e. if the rules do not allow or discourage unproductive and destructive activities, entrepreneurs and organizations focusing on productive activities take the lead, conducting the economy to the virtuous dynamic of growth and development.

As stated, the model developed by Baumol is very similar to the first version of North's Institutional Theory and, thus, it is also very coherent with normative policies aiming to counteract crime/violence and discourage tax evasion/corruption. In fact, as they are unproductive and destructive activities. By discouraging them, the entrepreneurial potential tends to be channeled towards developing innovations and productive activities, which is something that is not happening in the case of Brazil 
This inconsistency between the model and the reality relates to the second version of North's theory, where informal rules and dynamics of path dependence would explain the maintenance of corruption and stagnation. However, Baumol's model does not move forward in this direction. For the author, based on various historical facts, it is always possible to change the rules of the game towards a virtuous dynamic. Thus, "we do not have to wait patiently [as in North] for slow cultural change" (1993, p. 47).

\section{THE POSSIBILITY OF AN EXTENDED KEYNESIAN MODEL}

The most optimistic conclusions of the Baumol model, although they do not resolve the whole problem, make it clear that developing countries are not eternal prisoners of the culture of corruption. If this is true, the Brazilian failure to contain the advances of unproductive and destructive dynamics indicates that the existing rules and institutional arrangements are not efficient or, at least, sufficient to conduct entrepreneurial potential predominantly towards productive activities and innovations.

Why does this happen? Analyzing North and Baumol's conclusions, it is possible to say that, for both authors, the rules of the game and the quality of the players are important to determine the outcomes. The quality of the players, particularly in Baumol, is a result of the rules of the game; but what determines the rules of the game? This is the key question, which is not adequately explained by these authors.

For Baumol, the rules are simple choices of the government. As for North, they are a result of the interaction between institutions and organizations, given the path dependences generated by informal rules. As discussed before, both of the answers have their qualities, but they are not able to account for the great challenge, which is to build rules able to engender dominantly virtuous dynamics.

Against this backdrop, this article presents a new hypothesis: the effective rules of the game depend, above all, on the possible outcomes from the game itself. In other words, the government can choose the formal rules and they will interact with the informal rules, but what will determine the effective rules, those that will in fact guide the conduct of the entrepreneurs, are the potential results of the game.

In order to analyze this new hypothesis, we need to add to the theoretical institutional references a more macro and dynamic economic approach, which could be done through the Keynesian model of the economic cycle. For Keynes and here we refer to Keynes' General Theory - , as for Schumpeter, Baumol and, to some extent, North, the entrepreneur is a key piece to understand the economic dynamic. Therefore, it is from Keynesian entrepreneurial behavior that we try to expand the scope of the institutional analysis.

Although considering that the entrepreneur is equipped with 'animal spirits', Keynes argues that their decisions made based on expectations for the future do 
not vary in a predominantly erratic way. The assumption is that, with an uncertain future, the present reality takes a disproportionate role in forming expectations, which tend to stabilize in a unified way, at least for a certain period of time. ${ }^{9}$ On the other hand, entrepreneurs do not act as isolated micro-units. They are structured in an effective capital market, which, in addition to allowing leverage of a large flow of resources, also unifies expectations.

Keynes seeks to understand and explain the dynamic of the economic cycle based on this analysis of the expectations behavior and on the aggregate investment. According to his analysis, while the economy is expanding, the interest rate increases in parallel, faced with a relative shortage of the currency. However, with this optimism, a high expectation of profit also increases, marked by frenetic speculation, more than compensating for the cost, maintaining the expansive dynamic. This process extends in an interactive way until, for some reason, arising from an excess of production capacity or even an over-accumulation of stock, confidence in the future collapses, taking the expectation of profit with it.

Keynes observes that once a crisis has started, the pure and simple adoption of an expansive monetary policy, reducing the interest rate, is not enough to contain it. Given the fall in the level of confidence and, consequently, the low expectation of profit, investments lose their attractiveness, even with very low interest rates. Thus, reversal of a downward to upward movement requires recovering confidence in the economy. With resumed confidence, there are renewed expectations of profit and, consequently investments, taking the economy to a new virtuous cycle of growth.

As can be observed the Keynesian entrepreneur focuses on productive activities, in the same way as argued by Schumpeter. Thus, what determines the dynamic or the crisis is the entrepreneur action (or lack of action). However, as Baumol demonstrates, this vision is very limited, faced with the entrepreneurial possibilities of unproductive and destructive activities. Therefore, Baumol's example may comply with an Extended Keynesian Model, where the crisis does not only take place due to the lack of productive enterprises but also the development of unproductive and destructive innovations and activities.

Based on this new model, it is possible to identify the conditions to develop an analysis of the new hypothesis, that the effective rules of the game are determined by the possible outcomes of the game itself. In fact, as North and Baumol put forward, entrepreneurs choose for productive or unproductive and destructive enterprises according to the payoffs of each option. However, these payoffs, if the

\footnotetext{
${ }^{9}$ This explanation for the stability of expectations in the short term allows Keynes, in his General Theory, to focus all of his attention on interest rates. In fact, if expectations do not change, everything depends on the interest rate, which, to him, directly results from monetary policy, except in extreme situations (1936).
} 
agents are rational, can only be understood in relative terms, which significantly changes various conclusions of the institutional analysis.

In general terms, an entrepreneur only chooses an unproductive or destructive activity if the payoff is higher than for productive ones. Thus, the idea would be to establish rules of the game that reduce the payoffs for the socially undesirable activities. However, this will not necessarily engender innovations and productive activities that generate growth. What happens is that the payoff for these activities or, as Keynes would say, the expectation of payoffs for these activities, will vary according to the growth itself.

In fact, if there is growth or the possibility of growth, the expectations of payoffs/future profits increase, encouraging growing productive investments, generating jobs, salaries and increased revenue and so on, in a virtuous dynamic of growth and development. Obviously, this dynamic discourages unproductive and destructive activities, which start to present relatively low or even negative payoffs. However, if the economy is in crisis, even if the institutions exist or, that is, there are the same rules of encouragement and punishment, the expectations of future profits/payoffs decline and productive investments slow down. With the fall in investments, there will be unemployment and drop in salaries, relatively increasing the payoffs for unproductive and destructive activities. ${ }^{10}$

Therefore, in the new model the choice for productive activities goes together with growth and development, as well as unproductive and destructive activities going together with stagnation and crisis. However, the causality is basically the opposite of what institutional analysis proposes (see Figure 1 below). In effect, the optimal rules of incentive and punishment do not lead to productive activities and, therefore, to growth and development. Actually, it is growth, or at least the possibility of growth that promotes innovation and productive activities, validating and demanding rules to make them happen. It is the same for stagnation and crisis regarding innovation and unproductive and destructive activities. ${ }^{11}$

\footnotetext{
${ }^{10}$ It should be added that, in many cases, unproductive and destructive activities do not only increase their payoffs, but also transform into the only alternative available for various economic agents.

${ }^{11}$ It is important to observe that it is no coincidence that with the new model, a causality which is almost completely opposite to institutional analysis is reached. What happens is that both North and Baumol, although developing an institutional analysis, are clearly neoclassical economists. Thus, although they always set off implicitly from the presupposition that unless there is an undue intervention or, in other words, an undue rule, the economy will always be at the level of full employment. Thus, every institutional analysis is incomplete, in so far as it misses the macroeconomic question, only being concerned with microeconomic rules.
} 


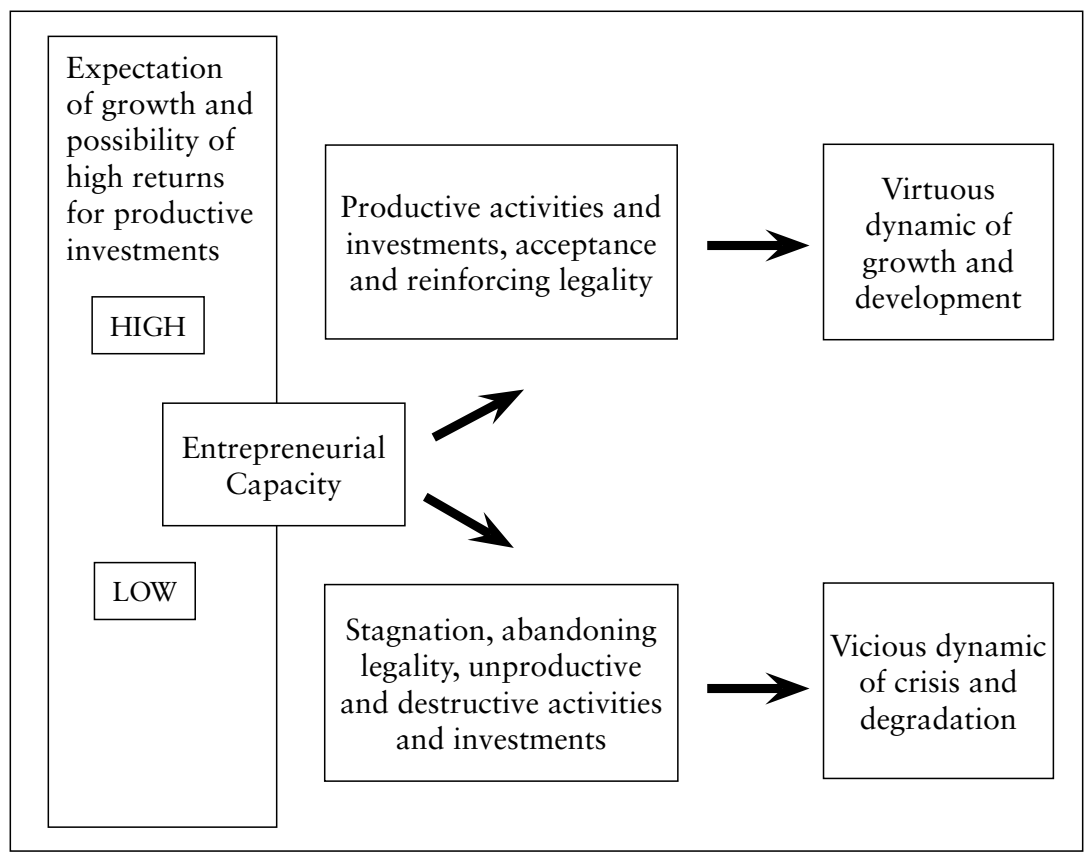

Source: Elaborated by the author.

\section{REANALYZING BRAZILIAN CRISIS}

As demonstrated, in the light of the Extended Keynesian Model proposed here, what takes place in the Brazilian economy is not a paradox. It is a refined example of the dynamics considered in the model. In fact, as the data presented in sections 2 and 3 shows, to the extent that the growth of productive activities in the economy slows down, unproductive and destructive ones accelerate, maintaining the fall in the unemployment rate, even with the advancing crisis. However, this dynamic, as far as unproductive and destructive activities hinder productive ones - as in the example of the Operation Car Wash - it is not sustainable in the medium to long-term. Thus, it is no coincidence that the unemployment rate increased explosively from the beginning of President Dilma's second term.

However, it should be clarified that the advancement of unproductive and destructive activities is not a dynamic exclusive to President Rousseff's government. The data presented in sections 2 and 3 demonstrate that these types of activity are in place for a long time in Brazil. It is possible to say that, in its current configuration, they started with the success of the economic plan that implemented the current currency (Real Plan). The plan led to price stabilization, which made it possible to accelerate growth based on productive activities. However, as the acti- 
vities were not put in place on an adequate scale, they paved the way for the advance of unproductive and destructive activities. In other words, in terms of the model, they allowed for idle entrepreneurial and working capacity that contributed to the set up of a financial system focused on rentier activities, as well as the emergence of corrupt entrepreneurs and criminals of all types and sizes.

And why did this happen? Why did productive activities not increase in an accelerated way and why did it take so long for the economic crisis to deepen (only appeared during President Dilma's terms)? The answer to these questions is connected to the attitude of the economists and politicians who were at the forefront of the Brazilian economy during these years, and the international environment. Generally speaking, it can be said that the economic policy formulators had never really been concerned with growth. Short-sighted, they were only concerned with stabilizing prices which, in theory, guarantees votes. And this stabilization was almost always sought through a strong or, overvalued currency (Real), achieved by keeping interest rates much higher than those practiced on the international market.

It is important to emphasize that, particularly in the Worker's Party (PT) governments, the over valuation process was not marginal but extremely expressive ${ }^{12}$. In order to understand its magnitude, Table 2 shows the evolution of the exchange rate between Brazil and China. It is possible to observe that the Real was $42.31 \%$ more expensive than the Yuan between 2003 and 2011. Overlooking internal price variations, this means that, solely with the exchange rate, independent of gains in productivity, on average, Chinese products were $29.73 \%$ cheaper than Brazilian ones during this period. With this process, clearly the production of a series of tradable goods became increasingly unfeasible in Brazil. Following the model, this explains both the accelerated deindustrialization, including the tourism industry, with low growth in general. ${ }^{13}$

Table 2: Evolution of the Exchange Rate and Real Growth: Brazil versus China

\begin{tabular}{|c|c|c|c|c|}
\hline \multirow{2}{*}{ Years } & \multirow{2}{*}{$\mathrm{R} \$ \mathrm{Y} \$$} & \multicolumn{2}{|c|}{ GDP Evolution, index base $100=2002$} & \multirow{2}{*}{$\begin{array}{c}\text { GDP } \\
\text { China/Brazil }\end{array}$} \\
\cline { 3 - 4 } & & Brazil & China & \\
\hline 2003 & 0.37 & 101.20 & 109.02 & 3.25 \\
\hline 2004 & 0.35 & 106.97 & 120.58 & 3.40 \\
\hline 2005 & 0.30 & 110.29 & 131.43 & 3.59 \\
\hline 2006 & 0.27 & 114.70 & 147.04 & 3.86 \\
\hline
\end{tabular}

\footnotetext{
12 The overvaluation of the currency (Real), associated with high interest rates, was one of the main economic policy instruments in President Cardoso's terms, particularly during his first term. For more on this point, see Giambiagi (2011, chap. 7).

${ }^{13}$ For in depth analyses of this process, see Bresser Pereira (2015), Filgueiras et al. (2012), Marconi and Barbi (2012) and Lacerda and Loures (2015).
} 


\begin{tabular}{|c|c|c|c|c|}
\hline 2007 & 0.26 & 121.58 & 164.74 & 4.08 \\
\hline 2008 & 0.26 & 127.66 & 173.17 & 4.09 \\
\hline 2009 & 0.29 & 127.40 & 187.28 & 4.43 \\
\hline 2010 & 0.26 & 137.09 & 203.15 & 4.46 \\
\hline 2011 & 0.26 & 142.43 & 219.05 & 4.63 \\
\hline 2012 & 0.31 & 144.99 & 235.92 & 4.90 \\
\hline 2013 & 0.35 & 148.91 & 254.09 & 5.14 \\
\hline 2014 & 0.38 & 149.06 & 272.63 & 5.51 \\
\hline \multirow{2}{*}{ Years } & \multirow{2}{*}{$\begin{array}{l}\text { Currency } \\
\text { Valuation }\end{array}$} & \multicolumn{2}{|c|}{ Annual Average Growth } & \multirow{2}{*}{ Average Ratio } \\
\hline & & Brazil & China & \\
\hline $2003 / 11$ & $42.31 \%$ & $4.01 \%$ & $9.11 \%$ & 3.98 \\
\hline $2003 / 14$ & $-2.63 \%$ & $3.38 \%$ & $8.72 \%$ & 4.28 \\
\hline
\end{tabular}

Source: Penn World Table 9.0. Feenstra, Inklaar and Timmer. (2015). Available at: http://www.rug.nl/ggdc/ productivity/pwt/.Elaborated by the author.

In fact, as observed in Table 2, Brazil only grew by $42.43 \%$ between 2003 and 2011, which is equivalent to an average of $4.01 \%$ per year. On the other hand, China, with a devalued, or perhaps more competitive Yuan, grew $119.05 \%$ in the same period, equivalent to an annual average of $9.11 \%$. With this, China's GDP, which was 3.25 times that of Brazil in 2003, reached the level of 4.63 times Brazilian GDP in 2011. It should also be observed that although the Real was devaluing in relation to the Yuan from 2011 onwards, China continued to grow more than Brazil ${ }^{14}$.

As observed, on average, the growth of productive activities in the Brazilian economy was very low. This is true both when comparing with the growth by China, and when comparing with Brazil during the Import Substitution Cycle. But how was it possible to maintain this process of growth, although low, with the Real over-valued for so long? It is here that the international environment comes into effect.

It happened that the price of commodities exploded in the international market, the world experienced a speculative boom and China was growing at rates close to $10 \%$ per year. This context provided Brazil with some room in the global market due to the production of commodities, which allowed for some income distribution of income, improving consumption and services, keeping a positive commercial

\footnotetext{
${ }^{14}$ The continuity of Chinese dynamism suggests that the growth experienced throughout these years, contrary to what took place in Brazil, unfolded into virtuous dynamics of technical progress and growing productivity, meaning that its superiority was no longer so dependent on benefits from exchange rate.
} 
balance, even with an overvalued Real. ${ }^{15}$ However, at the end of President Lula's second term, this scenario changed, China decelerated its growth and the price of commodities dropped. President Dilma's first term began in this context, where, again following the Model, various productive activities slowed down or even stopped and unproductive and destructive ones accelerated, explaining and aggravating the crisis and degradation of Brazilian socioeconomics/politics.

\section{CONCLUSION}

Although the proposal of solutions is not the central aim of this article, some conclusions and recommendations are inevitable considering the analysis developed. The first is that Brazil did not stop growing and is not experiencing an increasing degradation of its society because of the crisis. As observed here, the truth is exactly the opposite. The absence of appropriate growth is the reason Brazil has developed unproductive and destructive activities which, with the end of the accelerated international demand for commodities, becomes dominant and a start of disrupting several of the pillars of Brazilian democratic society.

In this context it does not make sense to try and combat the crisis with orthodox, classical fiscal adjustment strategies, associated with brutal rises in interest rates to contain inflation. These strategies, predominantly defended by economists directly or indirectly connected to the financial system, although with great delay, actually contain inflation but do cause difficulties to develop productive activities, with numerous public and private bodies becoming insolvent and leading the population to despair and/or migration to other unproductive and destructive activities. ${ }^{16}$ Thus, if these strategies are not properly reversed, the country will witness an expressive increase in unemployment, as well as the emergence of a number of arbitration fund operators, banks with their rentiers of working capital based on public debt, the new religions and their extremely profitable businesses, generalized corruption at all levels and spheres - independent of success of Operation Car Wash - and an increasingly more organized crime oppressing society.

But what should be the alternative to tackle all of this? The solution, shown very clearly by the model, is the effective resumption of development or, growth based on productive activities. Naturally, an effective resumption involves a difficult and complex set of reforms. However, the start of this process is not such a challenge. As significant international experiences demonstrate, everything depends on

\footnotetext{
${ }^{15}$ This dynamic of "luck" is what developmentalist literature calls the natural resource course, or Dutch disease, caused by "Ricardian rents which originate from the exploitation and export of abundant and cheap natural resources", which facilitate and encourage over-valuation of the currency (Bresser-Pereira, Oreiro and Marconi, 2016, p. 68).

${ }^{16}$ A further alternative is emigration. Or, that is, migration outside of the country; a path which, unfortunately, has been taken by a number of Brazilian people, including potential businessmen with high human capital, not willing to take the path of unproductive and destructive activities.
} 
making a gradual reduction in interest rates, allowing a gradual and continuous devaluation of the Real. ${ }^{17}$ It is important to highlight that this process, especially after overcoming the existing idle capacity, really needs to be very gradual. Being gradual, the increased price of imported goods, instead of accelerating inflation - as occurred with the reduction of interest rates attempted by President Dilma in 2012 - , can be compensated by a new and competitive expansion of the local productive base. ${ }^{18}$ With the resumption of the development process underway, other reforms (fiscal, labor, welfare, political and judicial) are much easier to implement. ${ }^{19}$

\section{REFERENCES}

ACEMOGLU, D. and ROBINSON, J. (2012) Por que as Nações Fracassam, São Paulo: Elsevier-Campus.

BAUMOL, W.J. (1993) “Entrepreneurship: productive, unproductive and destructive”. In: BAUMOL. W. J (ed.). Entrepreneurship, Management, and the Structure of Payoffs. Cambridge, Mass.: MIT Pres.

BRESSER-PEREIRA, L.C. (2015) “A quase-estagnação brasileira e sua explicação novo-desenvolvimentista”. In: BARBOSA, N. et al.. Industria e Desenvolvimento Produtivo no Brasil. Rio de Janeiro: Elsevier.

BRESSER-PEREIRA, L.C. (2016) “Teoria novo-desenvolvimentista: uma síntese”, texto apresentado no Centro Internacional, Celso Furtado, Rio de Janeiro, 11 de agosto de 2016. Disponível em: <http://www.bresserpereira.org.br/INDEX_g.asp. Acesso em 10 de out. de 2016.

BRESSER-PEREIRA, L.C., OREIRO, J.L. and MARCONI, N, (2016) Macroeconomia Desenvolvimentista: teoria política e econômica do novo desenvolvimentismo. Rio de Janeiro: Elsevier.

FENAVIST - Federação Nacional das Empresas de Segurança e Transportes de Valôres (2014), IV Estudo do Setor de Segurança Privada, Brasília. Disponível em <http://www.fenavist.com.br/static/ media/essegs/IV_ESSEG.pdf . Acesso em 3 de fev.de 2015.

FILGUEIRAS, L. et al.. (2012) “O desenvolvimento econômico brasileiro recente: desindustrialização, reprimarização e doença holandesa”. Revista da Desenbahia, Salvador, v. 9, n.17: 119-154.

\footnotetext{
${ }^{17}$ In fact, what is being proposed here is not very different to what was done by Canada, when facing its own crisis during the 1990s and, to some extent, by the USA in recent years, following 2008, with the policy of reducing interest rates associated to quantitative easing. Referring to the Canadian case, for example, Krugman observes that it involved "a combination of fiscal austerity and a large supply of money: [...] Canada drastically reduced its interest rates, encouraged private expenditure and allowed its currency to devalue, encouraging exports" (2015).

${ }^{18}$ Obviously not all of the inflationary impact will be avoided and, thus, to prevent it from spreading, at least temporarily, a slowdown in the indexation implicit in the current policy of readjusting the minimum salary would be required. On the other hand, the whole process should be conducted so as to converge towards what Macroeconomic Development calls an industrially balanced exchange rate. The rate that makes companies, which are technologically up-to-date in their respective sectors, producing tradable goods, competitive. See Bresser-Pereira (2016) and Bresser-Pereira, Oreiro and Marconi (2016).

${ }^{19}$ The central structure of this article was designed at the beginning of 2015 . Therefore, it was before President Dilma's impeachment and the radical fiscal adjustment experiments and interest rate policy adopted by President Temer's Government, whose implementation and consequent developments are not analysed here.
} 
FRAGA, E. (2015) “Com desistentes, taxa de desemprego no Brasil seria quase o dobro da atual”. Folha de São Paulo, São Paulo, 12 mar. 2015.

FREENSTRA, R. C., INKLAAR, R and TIMMER, M.P. (2015) "The next generation of the penn world table”. American Economic Review, 105(10), 3150-3182.

GECON - Grupo de Estudos de Conjuntura (2014) "Carta de Conjuntura”, IPEA, n.22, mar. 2014. Disponível em: < http://www.ipea.gov.br/portal/images/stories/PDFs/conjuntura/cc22_completa. pdf . Acesso em 7 de jul. de 2015.

GIAMBIAGI, F. (2011) “Estabilização, reformas e desequilíbrios macroeconômicos: os anos FHC”. In: GIAMBIAGI, F. et al.. Economia Brasileira Contemporânea: 1945-2010, Rio de Janeiro, Elsevier.

KEYNES, J.M. (1936 [1982]) A Teoria Geral do Emprego, do Juro e da Moeda. São Paulo: Atlas.

KRUGMAN, P. (2015) “A economia da Grécia é uma lição para os republicanos nos EUA”. Tradução The New York Times. UOL Noticias, em 10 de jul. de 2015. Disponível em: < https://noticias.uol. com.br/blogs-e-colunas/coluna/paul-krugman/. Acesso em 10 de jul. de 2015.

LACERDA, A.C. and LOURES, R.R. (2015) "Para o Brasil evitar o risco da desindustrialização". In: BARBOSA, N. et al.. Industria e Desenvolvimento Produtivo no Brasil, Rio de Janeiro: Elsevier.

MARCONI, N. and BARBI, F. (2012) "Taxa de câmbio e composição setorial da produção". In: HOLlAND, M. e NAKANO, Y. (orgs.). Taxa de Câmbio no Brasil. São Paulo: Elsevier - Campus.

MENEZES, N. (2014) “Jovens no Mercado de Trabalho", Valor Econômico, São Paulo, 17 de out.

DEPEN - Departamento Penitenciário Nacional (2014), Levantamento Nacional de Informações Penitenciárias - INFOPEN, Brasília. Disponível, em <http://www.justica.gov.br/seus-direitos/politica-penal/documentos/relatorio-depen-versao-web.pdf. Acesso em: 3 de fev.de 2015.

NORTH, D. (1981) Structure and Change in Economic History. New York: W.W. Norton.

NORTH, D. (1990) Institutions, Institutional Change and Economic Performance. Cambridge, Mass.: University Press.

PONTES, F. and CANDIDA, S. (2006) "O inimigo que fica na guarita", O Globo, Rio de Janeiro, 4 maio. Disponível em: <http://www2.senado.leg.br/bdsf/item/id/399924. Acesso em: 3 de fev.de 2015 .

SCHUMPETER, J. A. (1942 [1984]) Capitalismo, Socialismo e Democracia. Rio de Janeiro: Zahar Editores.

WAISELFISZ, J. (2014) Homicidios e Juventude no Brasil: Mapa da Violência. Brasília: Secretaria Geral da Presidência da República. 